\title{
Consensus
}

Volume 26

Issue 2 Apocalyptic

Article 18

$11-1-2000$

\section{Saving Jesus from those who are right: rethinking what it means to be Christian}

Oscar Cole-Arnal

Follow this and additional works at: http://scholars.wlu.ca/consensus

\section{Recommended Citation}

Cole-Arnal, Oscar (2000) "Saving Jesus from those who are right: rethinking what it means to be Christian," Consensus: Vol. 26 : Iss. 2 , Article 18.

Available at: http://scholars.wlu.ca/consensus/vol26/iss2/18

This Book Reviews is brought to you for free and open access by Scholars Commons @ Laurier. It has been accepted for inclusion in Consensus by an authorized editor of Scholars Commons @ Laurier. For more information, please contact scholarscommons@wlu.ca. 


\section{Saving Jesus from Those Who Are Right: Rethinking What It Means to Be Christian}

\section{Carter Heyward}

Minneapolis: Fortress Press, 1999

275 pages, \$32.75 Softcover

\section{I found Carter Heyward's Saving Jesus from Those Who Are Right a} profound exercise in stretching as well as an emotional roller coaster ride. Although I would not seek out such a book under most normal circumstances, either in my academic research or for inspirational reading, I was attracted to the title and felt compelled to read a work of Dr. Heyward whom I have admired and respected from afar. At the very least, Saving Jesus from Those Who Are Right has served to intensify that admiration and respect while at the same time frustrating me as if I were a piece of taffy being stretched in a myriad of directions. After all, I graduated from one of America's citadels of Lutheran orthodoxy in 1966, having been caught up in the theologies of the likes of Karl Barth, Emil Brunner, Reinhold Niebuhr and the Rudolph Bultmann school of hermeneutics and biblical studies. When I left seminary I knew I was "right", and l've been "right" ever since, even though that "right" has grown, shifted and evolved. Honed by civil rights, antiwar activities, trade union, and feminist struggles, I have focussed with passion and intensity in coalition with Christian activists caught up in the spirit of liberation theology. When I approached the work of Carter Heyward I expected to find a kindred spirit. And I did, but... but...

But she pulled a series of flanking operations on me, much as Walter Wink always does when I am caught up in my relentless crusading. First, l encountered a vulnerable courage as Dr. Heyward opened up her life and her long-term struggles over sexuality and her body, over her bulimia and her alcoholism - and she managed this without being self-absorbed. In so doing, she disarmed my desire to confront her with old-style theological weapons and rhetoric. Her constant themes of "love-justice", "liberation" and especially "mutuality" called me away from academic fencing to a spirit of solidarity. Her willingness to define "those who are right" includes all of us - right, left or in-between, and she knows full well that we all fall into this aggressive and war-like stance from time to time. So I dropped my guard, read and listened to her words. When I disagreed (which was often enough) l bemoaned the fact that we could not sit down and talk face to face, and where I agreed (and that most often), I celebrated within.

I recommend Saving Jesus from Those Who Are Right as a must-read textbook for seminary systematic theology courses, not in place of more traditional texts but rather in dialogue with them on a conscious equal setting. Too often we add such books as optional and thus perpetuate our old "right" ways. Finally, I feel I must highlight two facets of the book: 1) Her appended 
liturgies stand out with power and tenderness underscoring that meeting sisters and brothers at worship is essential stuff. 2) The material on forgiveness toward the end of the book may well be the most profound treatment of that central element of our faith that I have ever read. Thank you Dr. Carter Heyward for challenge and support in Saving Jesus from Those Who Are Right.

Oscar L. Cole-Arnal

Waterloo Lutheran Seminary

\section{Making Room: Recovering Hospitality as a Christian Tradition Christine Pohl}

Grand Rapids: Eerdmans, 1999

205 pages, \$22.00 Softcover

While most of us image "hospitality" as quaint tea cups with shortbread, Christine Pohl, professor of Christian social ethics at Ashbury Theological Seminary in Wilmore, Kentucky, has a different image. Making Room is her examination of a more basic, but essential expression of "welcoming" in the life of the church. Starting with the Hebrew tradition of hospitality, she turns to its expression in Christianity from the early church to the present and reminds us, in the words of Krister Stendahl, "Wherever, whenever, however the kingdom [of God] manifests itself, it is welcome."

Pohl gives us primary sources, both ancient and contemporary, in a readable style which will make this volume a valuable resource for church professional and laity alike. Through the writings of Lactantius, Jerome, Chrysostom, Calvin, Luther, John Wesley, Benedict, Dorothy Day, Jean Vanier, Henri Nouwen and a host of others, Pohl traces the rise and progressive decline of hospitality's role in Christian life as the church grew in size and power.

And there is the rub for Pohl. As the church became powerful and acceptable, it lost its counter-cultural and subversive nature. In essence, she asks, "How can you welcome the stranger or the 'other' if you are now the one in power?" Our contemporary times, however, have reversed that role; once more we become the "stranger" and the "other". Can we - will we - revive this meaningful counter-cultural and subversive dimension of our faith and welcome the other as "another Christ"?

In the book's section entitled, "Recovering the Practice", Pohl offers guidance on how the church can again become a welcoming community. Pohl is no idealist; she illustrates the commitment required and its frustrations. She offers direction on boundary setting and respite for hospitality givers and advice 